๑̈. В. Овчарук

ДВНЗ «Тернопільсъкий державний медичний університет імені І. Я. Горбачевсъкого МОЗ України»

\title{
ОПТИМІЗАЦІЯ МЕТОДІВ ДІАГНОСТИКИ ПРИ ЗАТРИМЦІ РОСТУ ПЛОДА У ВАГІТНИХ
}

ОПТИМІЗАЦІЯ МЕТОДІВ ДІАГНОСТИКИ ПРИ ЗАТРИМЦІ РОСТУ ПЛОДА У ВАГІТНИХ. У статТі представлені резУЛЬтатИ пошуку маркерів ранньої діагностики затримки росту плода та оцінка їх ефективності. Проведено дослідження 45 вагітних з затримкою росту плода, що перебували на лікуванні у Тернопільській комунальній міській лікарні № 2. Контрольну групу склали 25 вагітних з фрізіологічним перебігом вагітності, які народили живих доношених дітей з масо-ростовими характеристиками відповідно до гестаційного віку. Вивчали стан феетоплацентарного комплексу у вагітних на основі дослідження рівнів гормонів (ПАПП-А, $\beta$-хоріонічного гонадотропіну людини (ß-ХГЛ), естріолу (ЕЗ), плацентарного лактогену (ПЛ) та прогестерону). Стан внутрішньоутробного плода оцінювали за даними ультразвукового дослідження, кардіотокограсрії, визначення біосрізичного профрілю плода. Виявлено, що ранніми ознаками розвитку затримки росту плода є визначення ПАПП, естріолу та хоріонічного гонадотропіну в ранні терміни вагітності та рівні естріолу, прогестерону, плацентарного лактогену в другому триместрі. Використання гравідограми як скринінгового маркера дозволив діагностувати затримку росту й у 95,4 \% випадків був підтверджений УзД та виставлено діагноз затримки росту плода у вагітних. За даними Узд визначали біометричні маркери затримки росту.

ОПТИМИЗАЦИЯ МЕТОДОВ ДИАГНОСТИКИ ПРИ ЗАДЕРЖКЕ РОСТА ПЛОДА У БЕРЕМЕННЫХ. В статье представЛеНЫ результаты поиска маркеров ранней диагностики задержки роста плода и оценка их эффективности. Проведено исследование 45 беременных с задержкой роста плода, которые находились на лечении в Тернопольской коммунальной городской больнице № 2. Контрольную группу составили 25 беременных с фризиологическим течением беременности, родивших живых доношенных детей с массо-ростовыми характеристиками в соответствии с гестационным возрастом. Изучали состояние фетоплацентарного комплекса у беременных на основе исследования уровней гормонов (ПАПП-А, $\beta$-хорионического гонадотропина человека ( $\beta$-ХГЧ), эстриола (ЕЗ), плацентарного лактогена (ПЛ) и прогестерона). Состояние внутриутробного плода оценивали по данным ультразвукового исследования, кардиотокографии, определения биофизического профиля плода. Выявлено, что ранними признаками развития задержки роста плода является определение ПАПП, эстриола и хорионического гонадотропина в ранние сроки беременности и уровни эстриола, прогестерона, плацентарного лактогена во втором триместре. Использование гравидограмы как скринингового маркера позволил диагностировать задержку роста и в 95,4 \% случаев был подтвержден УЗИ и выставлен диагноз задержки роста плода у беременных.

OPTIMISATION METHOD FOR DIAGNOSING FETAL GROWTH AT A DELAY DURING PREGNANCY. The paper presents the results of early diagnosis markers growth retardation and evaluation of their effectiveness. A study of 45 pregnant women with fetal growth retardation, which were treated at the Ternopil City Community Hospital № 2. The control group consisted of 25 pregnant women with physiological pregnancy who gave birth to live full-term children with weight and by growth characteristics of the gestational age. Studied status placenta in pregnant based on a study hormone levels (Papp-A, $\beta$-human chorionic gonadotropin ( $\beta$-hCG), estriol (E3), placental lactogen (PL) and progesterone. State of fetus evaluated according to ultrasound, cardiotocography, determination biophysical profile of the fetus. revealed that the early signs of growth retardation is to determine Papp, estriol and human chorionic gonadotropin in early pregnancy and levels of estriol, progesterone, placental lactogen in the second trimester. Use hravidohramy as a screening marker allowed the diagnosis of growth retardation and in $95.4 \%$ of cases and was confirmed by ultrasound diagnosed fetal growth retardation in pregnant women.

Ключові слова: плід, затримка росту плода, естріол, хоріонічний гонадотропін, прогестерон, плацентарний лактоген.

Ключевые слова: плод, задержка роста плода, эстриол, хорионический гонадотропин, прогестерон, плацентарный лактоген.

Key words: fetus, fetal growth retardation, estriol, human chorionic gonadotropin, progesterone, placental lactogen.

ВСТУП. Затримка росту плода (ЗРП) має велику питому вагу в структурі причин перинатальної захворюваності і смертності, досягаючи $40 \%$, а репродуктивні втрати і витрати на комплексне лікування дітей з ЗРП є значними. Тому прагнення знизити перинатальну захворюваність і смертність при синдромі затримки росту плода стало причиною для пошуку основних принципів ранньої профілактики, своєчасної діагностики даного ускладнення вагітності $[1,2]$.

Дослідження ЗРП, як основного прояву плацентарної недостатності (ПН), є актуальним в акушерській практиці і має важливе соціальне значення для народження майбутніх здорових поколінь. Затримка росту плода - це ускладнення вагітності, яке є причиною антенатальної та інтранатальної смертності плода і призводить до захворюваності та смертності в ранньому неонатальному періоді [1]. Частота даної патології, за даними ВОО3, коливається від 31,1 \% в країнах Центральної Азії до 6,5% в країнах Європи. Актуальною залишається проблема антенатальної охорони плода та профілактика перинатальної смертності.

Затримка росту плода розвивається внаслідок плацентарної дисоункції і призводить до народження дитини з масо-ростовими показниками нижче 10 пер- 
центиля для даного терміну вагітності, а морфологічний індекс відстає на 2 тижні і більше від гестаційного віку. Затримка росту плода - одна з найбільш частих причин дистресу плода, високої перинатальної захворюваності та смертності [2, 3].

Наявність патологічних процесів у фетоплацентарному комплексі негативно впливає на стан плода, веде до затримки його росту (ЗРП), а перинатальна смертність при цьому ускладненні складає 35-40% [1]. Генетично детермінований потенціал росту плода в ході вагітності змінюється залежно від материнських, плацентарних і плодових фракторів, які в підсумку й визначають кінцеві масо-ростові показники новонародженого. Антенатальна діагностика затримки росту плода з наступною корекцією його стану $є$ важливим компонентом акушерської допомоги і формує напрямок перинатальної медицини, який вважає плід «повноправним» пацієнтом [3]. Серед причин затримки росту плода виділяють соціально-економічні, генетичні, імунологічні фрактори, екстрагенітальні захворювання, ускладнення під час даної вагітності $[1,2]$.

Ступінь важкості ЗРП є важливим параметром, який впливає на порушення функції центральної нервової системи, паренхіматозних органів та перебіг неонатального періоду. Останні літературні дані свідчать, що затримка росту плода впливає не тільки на масово-ростові параметри, але й змінює психомоторний розвиток плода і новонародженого [1]. Репродуктивні втрати і витрати на комплексне лікування, пов'язані з народженням дітей з затримкою росту плода, негативно впливають на демографічні показники та середню тривалість життя населення [5]. Медико-соціальна значимість проблеми визначається також тим, що в подальшому такі діти відстають у фізичному та інтелектуальному розвитку значно частіше, ніж доношені та недоношені діти, що мають нормальну для свого гестаційного віку масу тіла. Прогноз подальшого розвитку дитини залежить від варіанта та ступеня тяжкості затримки росту плода [3]. Незважаючи на наявні в літературі відомості з проблеми ЗРП, різні аспекти її в даний час вивчені не до кінця і продовжують досліджуватись. Розробка ефективних і достовірних методів діагностики затримки росту плода $є$ в даний час одним з найважливіших розділів перинатології [5].

Метою нашого дослідження був пошук ефективних і достовірних маркерів ранньої діагностики затримки росту плода.

МАТЕРІАЛИ ТА МЕТОДИ. Для вирішення поставлених завдань нами проведено дослідження 65 вагітних з затримкою росту плода, що перебували на лікуванні в Тернопільській комунальній міській лікарні № 2. Контрольну групу склали 25 вагітних 3 фрізіологічним перебігом вагітності, які народили живих доношених дітей 3 масо-ростовими характеристиками відповідно до гестаційного віку.

Стан фретоплацентарного комплексу у вагітних вивчали на основі дослідження рівнів гормонів (ПАПП-А, $\beta$-хоріонічного гонадотропіну людини ( $\beta$-ХГЛ), естріолу (Е3), плацентарного лактогену (ПЛ) та прогестерону) у терміни першого та другого триместрів [5]. Визначення гормонів феетоплацентарного комплексу здійснювали методом ІФА на апараті Stat Fax 303 Plus (США). Плацента відіграє роль залози внутрішньої секреції і синтезу гормонів. Проаналізовані дані пренатального скринінгу першого та другого триместрів. Статистичне оброблення отриманих результатів проводили на персональному комп'ютері за допомогою офісних програм «Microsoft Excel» із використанням основних статистичних методів розрахунку. Достовірність різниці середніх значень визначали з обчисленням критерію Стьюдента.

Стан внутрішньоутробного плода оцінювали за даними ультразвукового дослідження, кардіотокографії, визначення біофізичного профрілю плода та гравідограми плода. Ультразвукове обстеження вагітної, визначення біофізичного профрілю проводили на апаратах Voluson-730. Доплерометрію проводили на апараті Voluson-730 конвексними датчиками з частотою від 2 до 5 МГц, в режимах кольорового доплеру. Визначали антропометричні показники: біпарієтальний розмір (БПР), довжину стегна, лобно-потиличний розмір, середні діаметри грудної клітки і живота та співвідношення окружності голівки до окружності живота плода, співвідношення довжини стегнової кістки до окружності живота. При плацентографії оцінювали локалізацію плаценти, товщину їі та ступінь зрілості [6, 7]. Для запису кардіотокограм використовували монітор стеження за станом матері та дитини Cadence Basic і фетальний монітор Qiston BT-350 LCD. Запис проводили протягом 30 хв. Для аналізу кардіотокограм використовували шкалу W. Fisher та співавт., 1976. Оцінка у 8-10 балів відповідає нормальній КТГ, 5-7 балів вказують на початкові порушення стану плода, 4 бали і менше можуть вказувати на виражені порушення плода [7].

На основі проведення УЗД діагностовано затримку росту плода. Здійснення ультразвукової фретометрії виявило наявність асиметричної форми та симетричної затримки росту плода.

РЕЗУЛЬТАТИ ДОСЛІДЖЕННЯ ТА ЇХ ОБГОВОРЕННЯ. В результаті проведеного аналізу анамнестичних даних виділено такі критерії, які вказують на ризик розвитку ЗРП: вік вагітної (менше 19 або старше 40 років), низький зріст, екстрагенітальні захворювання, які суттєво частіше обумовлюють асиметричну форму ЗРП; обтяжений гінекологічний анамнез (у 43,1% вагітних з ЗРП проти 12,6 \% контрольної групи, р<0,05), народження маловагових дітей при попередніх вагітностях (у 4, 8 разів частіше відмічалось у жінок із ЗРП), куріння до вагітності (17,2\% проти 4,4 \% жінок контрольної групи, р<0,05). В основній групі більший відсоток першовагітних та першороділь. Слід звернути увагу на наявність ознак переривання вагітності в ранні терміни частіше в групі з розвитком

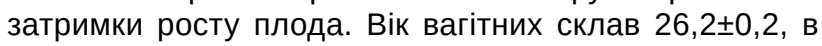
контролі - 26,9 $9 \pm 0,1$ року $(p<0,05)$.

На основі проведеного вивчення гормонів фретоплацентарного комплексу було виявлено порушення в обстежуваної групи жінок. При проведенні першого скринінгового дослідження в обстежуваних жінок рівень ХГЛ був достовірно нижчим, ніж у контрольній групі (табл. 1). Зростаючий рівень гонадотропіну вказує про наявність зачаття і розвитку вагітності. Його зростання відбувається досить швидко. Вже в I триместрі вагітності рівень ХГЛ збільшується в 2 рази, кожні 2 дні. Найвищої точки він досягає, приблизно, на 7-10 тижнях. Після цього його зростання йде на спад і залишається майже незмінним у другій половині вагітності.

Провівши аналіз даних таблиці 1, звертаємо увагу на те, що ПАПП-А є нижчим у групі обстежуваних з затримкою росту. Також нижчий рівень хоріонічного гона- 
Акушерство та гінекологія

Таблиця 1. Рівень гормонів фетоплацентарного комплексу в крові досліджуваних груп вагітних у I триместрі

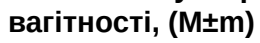

\begin{tabular}{|l|c|c||}
\hline \multicolumn{1}{|c|}{ Гормони фретоплацентарного комплексу } & Контрольна група, $\mathrm{n}=25$ & Основна група, $\mathrm{n}=45$ \\
\hline$\beta$-хоріонічний гонадотропін, мМО/мл & $43,45 \pm 0,71$ & $34,27 \pm 1,17^{*}$ \\
\hline Естріол, нг/мл & $0,64 \pm 0,15$ & $1,06 \pm 0,09^{*}$ \\
\hline ПАПП-А, мМо/мл & $2,76 \pm 0,63$ & $1,29 \pm 0,17^{\star}$ \\
\hline
\end{tabular}

Примітка. *- різниця достовірна порівняно з контролем, $p<0,05$.

дотропіну є прогностично несприятливою ознакою для подальшого розвитку вагітності.

При динамічному спостереженні за вагітною ведеться запис висоти стояння дна матки на гравідограмі (рис. 1).

При аналізі даних гравідограм виявляли відставання висоти стояння дна матки на 2,1 см в основній групі порівняно $з$ контролем. Отже, відставання на 2 см або відсутність приросту протягом 2-3 тижнів при динамічному спостереженні давало змогу запідозрити затримку росту плода.

За даними гравідограми виявлено відставання висоти стояння дна матки, що було показанням до ультразвукового обстеження. Порівняльний аналіз даних гравідограми та ультразвукової фетометрії дозволив виявити затримку росту плода у 95,4 \%.

При порівняльному аналізі гормонального профрілю вагітних, з затримкою росту плода, у II триместрі було встановлено, що в основній групі рівень плацентарних гормонів виявився достовірно нижчим, ніж у контрольній
( $<<0,05)$. При визначенні рівня прогестерону в динаміці перебігу вагітності рівень його зростав відповідно до терміну гестації, проте концентрації його в групі з затримкою росту плода були достовірно нижчими, ніж у контролі. Встановлена достовірна різниця у показниках рівня прогестерону: в основній групі він був у середньому в 1,2 раза нижчим за показники контрольної групи $(p<0,05)$. Зокрема, рівень ХГ був в 1,34 раза нижчим за показники контрольної групи. Аналогічна тенденція спостерігалась i при дослідженні рівня ПЛ, що в основній групі був нижчим в 1,6 раза порівняно з контролем. Звертало на себе увагу зниження рівня фетальних гормонів, так, вміст естріолу у вагітних основної групи був достовірно нижчим за показники контрольної групи (р<0,05) (табл. 2).

Таким чином, зміни в гормональному статусі у вагітних основної групи характеризувались зниженням рівня як фретальних, так і плацентарних гормонів, що свідчить про наявність істотних змін у плаценті, і сприяли розвитку плацентарної диссрункції.

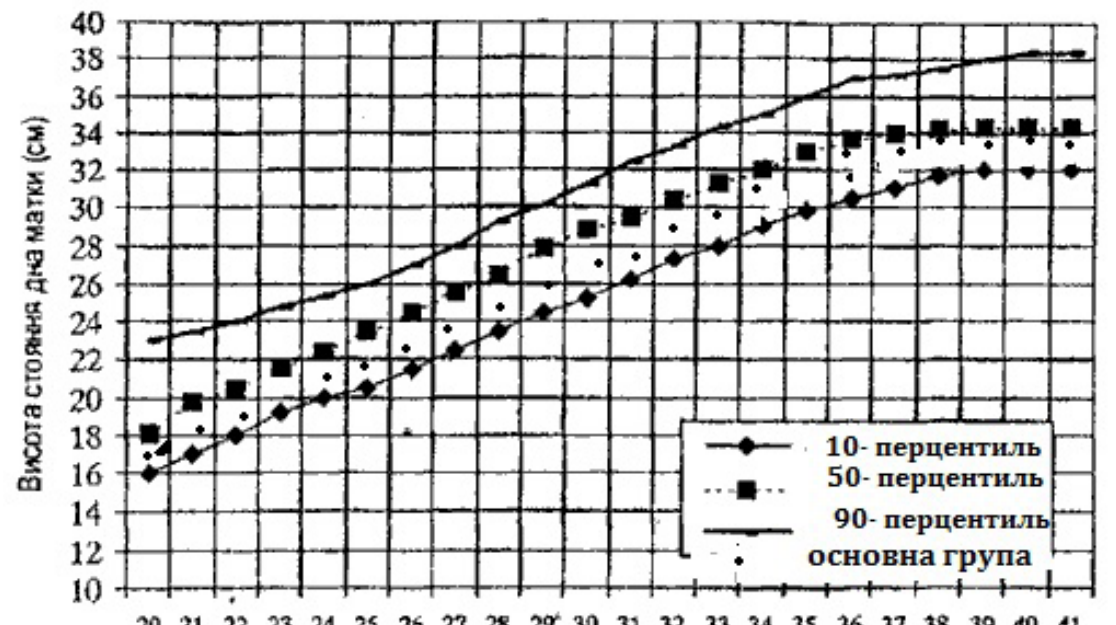

$\begin{array}{llllllllllllllllllllll}20 & 21 & 22 & 23 & 24 & 25 & 26 & 27 & 28 & 29 & 30 & 31 & 32 & 33 & 34 & 35 & 36 & 37 & 38 & 39 & 40 & 41\end{array}$

Термін вагітності (тижні)

Рис. 1. Гравідограма.

Таблиця 2. Рівень гормонів фетоплацентарного комплексу в крові досліджуваних груп вагітних у ІІ триместрі вагітності, (M士m)

\begin{tabular}{|l|c|c|}
\hline Гормони фретоплацентарного комплексу & Контрольна група, $\mathrm{n}=25$ & $\mathrm{I}$ група, $\mathrm{n}=45$ \\
\hline Хоріонічний гонадотропін, мОД/мл & $7541,45 \pm 136,71$ & $4913,27 \pm 219,17^{\star}$ \\
\hline Прогестерон, нг/ мл & $76,41 \pm 17,42$ & $26,67 \pm 8,94^{\star}$ \\
\hline Естріол, нг/мл & $1,94 \pm 0,15$ & $1,62 \pm 0,11^{*}$ \\
\hline Плацентарний лактоген, мг/л & $3,76 \pm 0,63$ & $2,74 \pm 0,19^{\star}$ \\
\hline
\end{tabular}

Примітка. *- різниця достовірна порівняно з контролем, p<0,05. 
Отримані дані дозволяють стверджувати, що рівень гормонопродукуючої функції плаценти може служити діагностичним критерієм для об'єктивної оцінки стану вагітної і плода, а також прогнозувати розвиток можливих ускладнень під час вагітності, у пологах та перинатальних ускладнень.

ВИСНОВКИ. 1. В результаті проведеного аналізу слід вважати ранніми маркерами затримки росту плода зниження рівня $\beta$-хоріонічного гонадотропіну людини та ПАПП-А при проведенні пренатального скринінгу першого триместру.

\section{СПИСОК ЛІТЕРАТУРИ}

1. Аналіз частоти та причини затримки росту плода, особливостей перебігу вагітності і пологів / В. П. Присяжнюк О. О. Кулик, О. М. Хвостик, С. Г. Кочко // Медико-соціальні проблеми сім'ї. - 2006. - Т. 11, № 3. - С. 56-59.

2. Маркін Л. Б. Діагностично-профрілактичні заходи при затримці функціонального диференціювання плаценти / Л. Б. Маркін, О. О. Михайлів // Педіатрія, акушерство та гінекологія. - 2008. - № 5. - С. 63-67.

3. Нікогосян Л. В. Ультразвукове дослідження фетоплацентарного комплексу при загрозі антенатальної загибелі плода / Л. Р. Нікогосян // Одеський медичний журнал. - 2012. - № 4. - С. 64-66.
2. Доцільно визначення рівнів плацентарних гормонів у сироватці крові в 20-21 тижні для діагностики порушень матково-плацентарних порушень при затримці росту плода.

3. Використання гравідограми як скринінгового маркера дозволив діагностувати затримку росту й у 95,4 \% випадків був підтверджений УзД та виставлено діагноз затримки росту плода у вагітних.

ПЕРСПЕКТИВИ ПОДАЛЬШИХ ДОСЛІДЖЕНЬ. ПрОдовжити роботу з діагностики та лікування затримки росту плода, покращити якість діагностики за рахунок використання нових методів.

4. Gardosi J. Preventing stillbirths through improved antenatal recognition of pregnancies at risk due to fetal growth restriction / J. Gardosi // Public Health. - 2014. - Vol. 128, № 8. P. 698-702.

5. Barker D. J. Placental programming of chronic diseases, cancer and lifespan: a review / D. J. Barker, K. L. Thornburg // Placenta. - 2013. - Vol. 34, № 10. - P. 841-845.

6. Ritz E. Prenatal programming-effects on blood pressure and renal function / E. Ritz // Nat. Rev. Nephrol. - 2011. - Vol. 7, № 3. - P. 137-144.

7. Sebire N. J. Correlation of placental pathology with prenatal ultrasound findings / N. J. Sebire, W. Sepulveda // J. Clin. Pathol. - 2008. - Vol. 61, № 12. - P. 1276-1284.

Отримано 15.08 .16 